Arq. Bras. Med. Vet. Zootec., v.73, n.6, p.1249-1259, 2021

\title{
Risk factors related to the appearance of umbilical disorders in dairy calves
}

[Fatores de risco relacionados ao surgimento de afecções umbilicais em bezerros leiteiros]

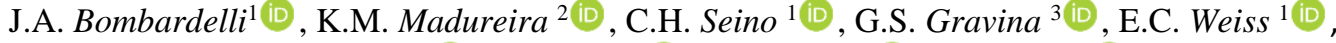 \\ C.L. Shecaira $^{1}$ (D), G.A. Reis ${ }^{1}$ (D) F.J. Benesi ${ }^{4}$ (D) , V. Gomes ${ }^{4}$ (D) \\ ${ }^{1}$ Graduate, Universidade de São Paulo, Faculdade de Medicina Veterinária e Zootecnia, Butantã, SP, Brasil \\ ${ }^{2}$ Universidade Federal da Bahia, Escola de Medicina Veterinária, Salvador, BA, Brasil \\ ${ }^{3}$ Practitioner, Rio de Janeiro, RJ, Brasil \\ ${ }^{4}$ Universidade de São Paulo, Faculdade de Medicina Veterinária e Zootecnia, Butantã, SP, Brasil
}

\begin{abstract}
The objective of this study was to determine the types of calve housing used in dairy farms, the prevalence of umbilical disorders and related risk factors. The 16 farms studied were visited to characterize the types of installation and possible risk factors, as well as information obtained from a questionnaire applied to the farmers. 806 Holstein calves were physically examined, in addition to collecting blood samples for the evaluation of Failures in Passive Immunity Transfer (FPIT), in animals that manifested inflammatory omphalopathies, and were also submitted to ultrasound examination. The prevalence of omphalopathies was assessed by Fisher's test, and multivariate logistic regression to assess risk factors. Eight types of installation were found: tropical house, suspended cage, collective stall, collective picket, Argentinean type, single-story cage, individual stall, and collective picket with chain. Omphalopathies accounted for $6.45 \%$ of the calves. Small size farms (up to 99 lactation cows) had high risk for umbilical disorders, ground floor collective calves, without side protection, with sand floor, in closed sheds and without heatstroke were considered risk factors for omphalopathies. Adequate colostrum and umbilical antisepsis are not associated with disease, its appearance being related to the housing conditions of the animals.
\end{abstract}

Keywords: omphalopathies, neonates, ultrasound, colostrum, calve housing

\section{RESUMO}

O objetivo deste estudo foi determinar os tipos de alojamento para bezerros leiteiros, a prevalência de onfalopatias e os fatores de risco relacionados. As 16 fazendas estudadas foram visitadas buscando-se caracterizar os tipos de instalação e os possíveis fatores de risco, além de informações obtidas de um questionário aplicado aos fazendeiros. Foram examinados fisicamente 806 bezerros da raça Holandesa, além da coleta de amostras de sangue, para avaliação da falha de transferência de imunidade passiva (FTIP), nos animais que manifestaram onfalopatias inflamatórias, sendo submetidos também ao exame ultrassonográfico. A prevalência das onfalopatias foi avaliada por teste de Fisher, e foi feita regressão logística multivariada a fim de se avaliarem os fatores de risco. Verificou-se oito tipos de instalação: casinha tropical, gaiola suspensa, baia coletiva, piquete coletivo, bezerreiro tipo argentino, gaiola térrea, baia individual e piquete coletivo com corrente. As onfalopatias corresponderam a 6,45\% dos bezerros. Os bezerreiros coletivos térreos, sem proteções laterais, com piso de areia, borracha, concreto ou madeira, em galpões fechados, sem insolação, com alta densidade animal, antissepsia umbilical realizada por três dias e FTIP acima de 50\% foram considerados fatores de risco para onfalopatias e possuem relação com o bezerreiro, sendo decisivas para evitar essas condições a colostragem e a antissepsia umbilical adequadas.

Palavras-chave: onfalopatias, neonatos, ultrassonografia, colostro, bezerreiros

Corresponding author: juliana.bombardelli@usp.br

Submitted: February 20, 2021. Accepted: August 9, 2021. 


\section{INTRODUCTION}

Calves are vulnerable to various diseases during the neonatal period, with umbilical conditions being of great importance (Fordyce et al., 2018) since these present mortality rates in Brazil around $6.3 \%$ (Azevedo et al., 2020). In animals with an improper management of colostrum, this rate can reach up to $11.1 \%$, considering that the mortality rate acceptable for animals with umbilical diseases must be less than 5\% (Azevedo et al., 2020).

Umbilical problems cause great economic losses, since they decrease weight gain and survival in herds, generate costs with medicines and veterinary assistance and increase the incidence of other neonatal diseases, and can even lead to death (Virtala et al., 1996). Comfort and well-being are also compromised, as animals spend less time lying down because of abdominal pain generated by the inflammatory process (Studds et al., 2018). The navel consists of the veins, arteries, and urachus (Spurway et al., 2012). After a few days of birth, the abdominal wall of the umbilical region closes completely at 3 to 4 weeks (Bombardelli et al., 2018), and the arteries and veins undergo fibrosis giving rise to the lateral ligament of the bladder and round ligament of the liver, respectively, and progressive atrophy of the urachus occurs and it becomes a trace in the urinary vesicle (Mulon and Desrochers, 2005; Baird, 2008)

Cleaning of the umbilical stump must be performed immediately at birth and maintained until its complete mummification (Fordyce et al., 2018) because exposure to environmental pathogens can cause inflammation and slow and irregular regression of structures (Mulon and Desrochers, 2005; Guerri et al., 2019). Inadequate hygiene conditions at the time of parturition, precarious post-birth umbilical disinfection, failure in the transfer of passive immunity, and inadequate handling of facilities where calves are kept in the first few days of life are considered important risk factors for the conditions of the umbilicus, which may impact the future productivity of dairy herds (Windeyer et al., 2013).

Thus, the assessment of risk factors is important, as it can promote the standardization of protocols that aim to minimize morbidity, mortality, and greater production efficiency (Desrochers and Francoz, 2014; Hopker, 2014). Therefore, the objective of this study was to determine the risk factors for umbilical disorders in dairy calves and to characterize their prevalence in the state of São Paulo.

\section{MATERIAL AND METHODS}

This work was approved by the Ethics Committee on Use of Animals - CEUA (protocol number 4410040716) from the Faculty of Veterinary Medicine and Zootechnics of the University of São Paulo (FMVZ/USP) and conducted between January 2016 and December 2017, in 16 dairy farms in the central-eastern region of the state of São Paulo, Brazil.

The first visit to properties consisted of checking the types of calve housing and risk factors that could be related to the emergence of umbilical disorders. A detailed characterization of the types and conditions of calve housing in each property was conducted by observation. Furthermore, a questionnaire was applied to the employees or owners of the farms, with the purpose of obtaining the largest possible amount of information on the management of animals and housing.

The questionnaire obtained information, such as the number of lactating animals, so that it was possible to characterize the property as small (up to 99 lactating cows), medium (from 100 to 499 lactating cows), or large (500 or more lactating cows) (USDA-NAHMS, 2014). It was also identified if females and males, or only females, were raised. Questions regarding the housing of calves, antisepsis of the umbilical region, and colostrum of newborns were also included (Table 1). 
Table 1. Information regarding the calve housing, antisepsis of the umbilical region, and colostrum of newborns

\begin{tabular}{|c|c|c|c|c|}
\hline Farm conditions & $\begin{array}{l}\text { Calve housing } \\
\text { conditions }\end{array}$ & Accommodations & $\begin{array}{c}\text { Umbilical } \\
\text { management }\end{array}$ & Colostrum \\
\hline Herd size & Individual/Collective & Floor & Antisepsis & Supply \\
\hline \multirow{4}{*}{$\begin{array}{c}\text { Calves: } \\
\text { females/males }\end{array}$} & Density & Location & Antiseptics & Quantity \\
\hline & Type & Bed (neonates) & $\begin{array}{l}\text { Antisepsis } \\
\text { frequency }\end{array}$ & $\begin{array}{c}\text { Days of } \\
\text { supply }\end{array}$ \\
\hline & & Humidity & $\begin{array}{l}\text { Antisepsis } \\
\text { period }\end{array}$ & $\begin{array}{c}\text { FPIT } \\
\text { (percentage) }\end{array}$ \\
\hline & & $\begin{array}{c}\text { Sunshine } \\
\text { Ventilation } \\
\text { Hygiene } \\
\text { Maintenance }\end{array}$ & Cord cut & \\
\hline
\end{tabular}

Legend: Herd size: small (up to 99 lactating cows), medium (from 100 to 499 lactating cows), large (500 or more lactating cows); Density: acceptable (distance between animals greater than 2 meters, for individual calves and with a space greater than $8.5 \mathrm{~m} 2 /$ animal, for collective calves), medium (distance less than 2 meters, but without contact between animals, in individual calve housing and with space between 5 and $8.5 \mathrm{~m} 2 /$ animal in collective calve housing), high (distance that allowed contact between calves, in the case of individual calve housing, and with space less than 5 $\mathrm{m}$ 2/animal, in the case of collective calve housing); Type: tropical house, suspended cage, collective stall, collective picket, Argentinean type, single-story cage, individual stall, collective picket with chain; Floor; (concrete, earth, sand, wood, rubber); Location: shed, pickets; Bed: yes, no; Humidity: adequate, high; Sunshine: adequate (the animal could expose or protect itself from the sun as it wished), inadequate; Ventilation: present, absent; Hygiene: performed, infrequent; Maintenance: yes, no.

Regarding the characteristics of calve housing, they were classified as individual or collective, evaluating the density of animals and classifying them as acceptable (distance between animals greater than 2 meters for individual calves and with a space greater than $8.5 \mathrm{~m}^{2} /$ animal for collective calves); medium (less than 2 meter distance, but without contact between animals, in individual calve housing and with space between 5 and $8.5 \mathrm{~m}^{2} /$ animal in collective calve housing); or high (distance that allowed contact between calves, in the case of individual calve housing, and with space below $5 \mathrm{~m}^{2} /$ animal in the case of collective calve housing) (Azevedo et al., 2008; Bittar and Ferreira, 2010).

The type of calve housing was defined by having top and side protection, the type of floor, if it was located in sheds or pickets, and if a bed of hay was placed for the thermal comfort of newborns. The calf housing humidity was also considered, whether it was high or adequate, if it had sufficient sunshine and ventilation, if it had good hygiene, and if frequent maintenance was conducted.
During the observation of the properties and application of the questionnaire, information was obtained for the analysis of the risk factors for inflammatory omphalopathies. To characterize the risk factors related to the umbilicus, it was defined as whether an antiseptic was used in this region immediately after birth and which antiseptic was used, its concentration and cleaning frequency, and whether the post-birth umbilical cord was cut. In relation to colostrum, information was provided on how colostrum was supplied, its quantity, and number of days of supply.

In studied properties, all male and female Holstein calves $(n=806)$ were evaluated weekly, from the week of birth, until they were 30 days old or until the moment of umbilical disease manifestation, respecting the maximum period of 30 days after birth. The evaluation consisted of the physical examination of the animal, in which vital parameters were evaluated, and the specific examination of the umbilical region, through palpation. Blood samples were obtained from all the animals evaluated and collected in tubes without anticoagulant. A blood collection was performed in 806 animals, aged from two to eight 
days of life, for future investigation of failures in passive immunity transfer (FPIT), in which blood serum was subsequently obtained and frozen, for future evaluation of samples from selected animals. The collections and evaluations of the animals were always carried out in the morning, during which visits were carried out.

Umbilical evaluation was performed weekly in the morning, consisting of physical examination of external and internal components by inspection and bimanual abdominal palpation, as described by Watson et al. (1994), performed on animals up to 30 days old. The 52 animals that showed umbilical changes identified on physical examination were subjected to ultrasound examination, in mode $\mathrm{B}$, of the umbilical components (Bombardelli et al., 2018) to confirm the changes. To this end, M5vet equipment (Mindray Medical Brazil Limited, São Paulo, SP) was used, with a linear transducer maintained at a frequency of $7.5 \mathrm{MHz}$. The findings obtained in physical and ultrasound examinations allowed the classification of umbilical alterations as inflammatory (including omphalitis, omphalophlebitis, omphaloarteritis, and omphalouraquitis) and fibrosis in the umbilicus.

In 39 of 52 animals in which inflammatory umbilical disorders were diagnosed, biochemical examinations were performed to assess possible FPIT. The samples were collected between 24 and 48 hours of the newborn calf's life (Feitosa et al., 2010) to determine the total serum proteins (TP), globulins (GLOB), and enzymatic activity of the gamma-glutamyltransferase (GGT).

TP was determined by refractometry, considering FPIT values below 5.0g/dL (Godden et al., 2019). The serum albumin rate was first determined by a colorimetric method for globulins, using an automatic biochemical analyzer (Randox ${ }^{\circledR}$ RX Daytona). The GLOB concentration was calculated by subtracting the albumin value from the total TP value, considering GLOB values below $2.25 \mathrm{~g} / \mathrm{dL}$ as indicative of FPIT (Hill, 2010). The serum activity of GGT was determined by a colorimetric kinetic method, using a commercial kit, according to a modified technique by Szasz (1974), and values below 100 IU/L were interpreted as indicative of FPIT (Feitosa et al., 2010). The animals that presented TP rates, GLOB and GGT values below the reference values, were considered with FPIT. FPIT analysis was also used to ascertain the risk factor for inflammatory omphalopathies on farms with $50 \%$ or more of diagnosed calves with FPIT.

The prevalence of umbilical disorders and their association with properties was performed using the Fisher's test, using the RStudio statistical software, with the level of significance considered when $p \leq 0.05$ and trend when $p \geq 0.05$ and $\leq 0.1$. Multivariate logistic regression models were used to determine the risk factors for umbilical disorders (PROC LOGISTIC procedure in SAS 9.4; SAS Institute, Cary, NC, USA). Initially, variables that showed significance of $p<0.3$ were selected to enter the univariate logistic regression model. The variables that did not show a p-value $<0.3$ after evaluation in the model were excluded by reverse elimination, while the others were checked for confounding effects, observing the changes in the coefficients. Those values that changed the coefficients by more than $30 \%$ were considered confusing. The linearity of the continuous predictors that remained in a model was verified, with its quadratic term being offered, and the F test of its association with the outcome was verified. The one with the smallest Akaike information criterion was selected as the final model.

\section{RESULTS}

Among the 16 properties studied, the following eight different types of facilities were found: tropical house $(6 / 16 ; 37.5 \%)$, suspended cage $(3 / 16 ; 18.75 \%)$, collective stall $(3 / 16 ; 18.75 \%)$, collective picket $(3 / 16 ; 18.75 \%)$, Argentinean type $(2 / 16 ; 12.5 \%)$, single-story cage $(1 / 16$; $6.2 \%)$, individual stall $(1 / 16 ; 6.2 \%)$, and collective picket with chain $(1 / 16 ; 6.2 \%)$.

Data were obtained on the herd size of the evaluated properties, being small $(11 / 16 ; 68.75 \%)$ or medium $(5 / 16 ; 31.25 \%)$, and on the density in calve housing, being low $(7 / 16 ; 43.75 \%)$, medium $(3 / 16 ; 18.75 \%)$, or high $(6 / 16 ; 37.5 \%)$. It was also identified whether males and females were raised $(9 / 16 ; 56.25 \%)$ or only females $(7 / 16 ; 43.75 \%)$. The results of the herd and calve housing observations are shown in Table 2.

Information was also obtained on whether the housing had side protection $(11 / 16 ; 68.75 \%)$, or were unprotected $(5 / 16 ; 31.25 \%)$; on the type of floor, earth $(8 / 16 ; 50 \%)$, concrete $(4 / 16 ; 25 \%)$, $\operatorname{wood}(2 / 16 ; 12.5 \%)$, rubber $(1 / 16 ; 6,2 \%)$, or sand 
$(1 / 16 ; 6.2 \%)$; on location, if they were in sheds $(9 / 16 ; 56.25 \%)$ or pickets $(7 / 16 ; 43.75 \%)$; whether there were hay beddings for the newborns $(6 / 16 ; 37.5 \%)$; whether the humidity was adequate $(11 / 16 ; 68.75 \%)$ or high $(5 / 16 ; 31.25 \%)$; if the sunlight was adequate (the animal could expose or protect itself from the sun as it wished) $(10 / 16 ; 62.5 \%)$; if the animals were kept in a totally shaded place $(5 / 16 ; 31.25 \%)$ or if they had permanent exposure to the sun $(1 / 16 ; 6.2 \%)$; if frequent cleaning of the housing was performed $(10 / 16 ; 62.5 \%)$, if it was infrequent $(3 / 16$; $18.75 \%)$, or not performed at all $(3 / 16 ; 18.75 \%)$; if the location was ventilated $(14 / 16 ; 87.5 \%)$ or if ventilation was absent $(2 / 16 ; 12.5 \%)$; and if calve housing maintenance was performed $(10 / 16$; $62.5 \%)$.

Table 2. Information about the herd and calve housing obtained during initial observations

\begin{tabular}{|c|c|c|c|c|c|c|c|c|c|c|c|c|c|c|c|c|c|c|c|c|}
\hline \multicolumn{14}{|c|}{ Calve housing observations } & \multicolumn{4}{|c|}{ Navel antisepsis } & \multicolumn{3}{|c|}{ Colostrum } \\
\hline 1 & S & $\mathrm{F}$ & $\mathrm{L}$ & $\begin{array}{c}\mathrm{CS} / \mathrm{CP} \\
(\mathrm{Mi})\end{array}$ & Y & C & $S$ & $\mathrm{~N}$ & A & A & $\mathrm{P}$ & $\mathrm{P}$ & Y & I-* & * & $*$ & $\mathrm{~N}$ & $*$ & $*$ & $*$ \\
\hline 2 & S & $\mathrm{F} / \mathrm{M}$ & $\mathrm{L}$ & $\mathrm{TH}(\mathrm{I})$ & $\mathrm{Y}$ & E & S & $\mathrm{N}$ & $\mathrm{H}$ & S & $\mathrm{N}$ & $\mathrm{AB}$ & $\mathrm{N}$ & $\mathrm{I}-10 \%$ & SID & $3 \mathrm{D}$ & $\mathrm{Y}$ & $4 \mathrm{D}$ & $6 \mathrm{~L}$ & $\mathrm{Ba}$ \\
\hline 3 & S & $\mathrm{F} / \mathrm{M}$ & $\mathrm{H}$ & $\mathrm{CS}(\mathrm{C})$ & $\mathrm{N}$ & E & S & $\mathrm{N}$ & $\mathrm{H}$ & S & $\mathrm{N}$ & $\mathrm{P}$ & $\mathrm{N}$ & I-* & * & * & $\mathrm{N}$ & $*$ & * & $\mathrm{T}$ \\
\hline 4 & $\mathrm{Md}$ & $\mathrm{F} / \mathrm{M}$ & $\mathrm{H}$ & $\mathrm{SC}(\mathrm{I})$ & $\mathrm{N}$ & $\mathrm{R}$ & S & Y & A & A & $\mathrm{P}$ & $\mathrm{P}$ & Y & I- $10 \%$ & SID & $5 \mathrm{D}$ & $\mathrm{Y}$ & $3 \mathrm{D}$ & $6 \mathrm{~L}$ & $\mathrm{Ba}$ \\
\hline 5 & $\mathrm{~S}$ & $\mathrm{~F} / \mathrm{M}$ & Md & $\mathrm{TH}(\mathrm{I})$ & Y & E & $\mathrm{P}$ & Y & A & A & P & $\mathrm{P}$ & Y & I-10\% & $*$ & $3 \mathrm{D}$ & $\mathrm{Y}$ & $3 \mathrm{D}$ & $4 \mathrm{~L}$ & $\mathrm{Ba}$ \\
\hline 6 & $S$ & $\mathrm{~F}$ & $\mathrm{~L}$ & $\mathrm{TH}(\mathrm{I})$ & Y & $S$ & $\mathrm{P}$ & Y & A & A & $\mathrm{P}$ & $\mathrm{P}$ & Y & I-10\% & SID & 1D & $\mathrm{Y}$ & $3 D$ & $4 \mathrm{~L}$ & $\mathrm{Ba}$ \\
\hline 7 & $S$ & $\mathrm{~F} / \mathrm{M}$ & L & $\begin{array}{c}\text { CP/SS } \\
(\mathrm{Mi})\end{array}$ & $\mathrm{Y}$ & C & S & Y & A & A & P & $\mathrm{P}$ & Y & I-10\% & SID & $3 \mathrm{D}$ & $\mathrm{N}$ & $4 \mathrm{D}$ & $4 \mathrm{~L}$ & $\mathrm{Ba}$ \\
\hline 8 & $\mathrm{Md}$ & $\mathrm{F} / \mathrm{M}$ & $\mathrm{H}$ & $\mathrm{A}(\mathrm{I})$ & $\mathrm{Y}$ & W & S & Y & $\mathrm{H}$ & $\mathrm{S}$ & P & $\mathrm{P}$ & $\mathrm{N}$ & I-10\% & TID & $5 \mathrm{D}$ & $\mathrm{Y}$ & $3 D$ & $6 \mathrm{~L}$ & $\mathrm{Ba}$ \\
\hline 9 & $\mathrm{Md}$ & F & Md & $\mathrm{TH}(\mathrm{I})$ & Y & E & $\mathrm{P}$ & $\mathrm{N}$ & A & A & $\mathrm{P}$ & $\mathrm{P}$ & Y & I-10\% & SID & $5 \mathrm{D}$ & $\mathrm{N}$ & $3 D$ & $4 \mathrm{~L}$ & $\mathrm{Ba}$ \\
\hline 10 & $\mathrm{Md}$ & $\mathrm{F}$ & $\mathrm{H}$ & A (I) & $\mathrm{N}$ & E & $\mathrm{P}$ & $\mathrm{N}$ & A & A & $\mathrm{P}$ & $\mathrm{P}$ & Y & I-10\% & SID & $2 \mathrm{D}$ & $\mathrm{N}$ & 1D & $2 \mathrm{~L}$ & B \\
\hline 11 & S & $\mathrm{F}$ & $\mathrm{L}$ & $\mathrm{TH}(\mathrm{I})$ & $\mathrm{N}$ & E & $\mathrm{P}$ & $\mathrm{N}$ & A & A & I & $\mathrm{P}$ & $\mathrm{N}$ & I-* & $*$ & * & $\mathrm{N}$ & $*$ & $*$ & * \\
\hline 12 & S & $\mathrm{F} / \mathrm{M}$ & $\mathrm{L}$ & $\begin{array}{l}\mathrm{TH} / \mathrm{CS} \\
\text { (I) }\end{array}$ & $\mathrm{Y}$ & E & $\mathrm{P}$ & $\mathrm{N}$ & A & A & $\mathrm{P}$ & $P$ & $\mathrm{Y}$ & I-* & $*$ & $*$ & $\mathrm{~N}$ & $*$ & $*$ & $*$ \\
\hline 13 & Md & $\mathrm{F} / \mathrm{M}$ & $\mathrm{H}$ & $\begin{array}{c}\mathrm{CS} / \mathrm{SC} \\
(\mathrm{Mi})\end{array}$ & Y & C & S & $\mathrm{N}$ & $\mathrm{H}$ & S & $\mathrm{N}$ & $\mathrm{AB}$ & $\mathrm{N}$ & I-10\% & SID & 1D & $\mathrm{Y}$ & $3 \mathrm{D}$ & $6 \mathrm{~L}$ & $\mathrm{Ba}$ \\
\hline 14 & $\mathrm{~S}$ & $\mathrm{~F}$ & $\mathrm{H}$ & $\mathrm{SC}(\mathrm{I})$ & $\mathrm{Y}$ & W & $S$ & $\mathrm{~N}$ & A & A & I & $\mathrm{P}$ & Y & $\mathrm{I}-5 \%$ & SID & 1D & $\mathrm{N}$ & $3 \mathrm{D}$ & $4 \mathrm{~L}$ & $\mathrm{Ba}$ \\
\hline 15 & $\mathrm{~S}$ & $\mathrm{~F} / \mathrm{M}$ & $\mathrm{L}$ & $\begin{array}{c}\mathrm{GC} / \mathrm{CP} \\
(\mathrm{Mi})\end{array}$ & $\mathrm{Y}$ & $\mathrm{C}$ & S & $\mathrm{Y}$ & $\mathrm{H}$ & S & I & $\mathrm{P}$ & $\mathrm{N}$ & I-10\% & * & $5 \mathrm{D}$ & $\mathrm{N}$ & $*$ & * & $*$ \\
\hline 16 & $\mathrm{~S}$ & F & Md & $\mathrm{CP}(\mathrm{C})$ & $\mathrm{N}$ & E & $\mathrm{P}$ & $\mathrm{N}$ & A & $\mathrm{P}$ & P & $\mathrm{P}$ & Y & NR & NR & NR & $\mathrm{N}$ & $*$ & $*$ & $*$ \\
\hline
\end{tabular}

Legend: $\mathrm{Si}=$ Size; Ge = Gender; Den = Density. Ty = Type; SPro = Side protection; Fl = Floor; Loc = Location; Hum = Humidity; Sun = Sunlight Clean = Cleaning; Vent = Ventilation; Main = Maintenance; Size $(\mathrm{S}=$ small $($ up to 99 lactating cows $) ;$ Md = medium (from 100 to 499 lactating cows)); Gender ( $\mathrm{F}=$ female; $\mathrm{M}=$ male); Density ( $\mathrm{L}=$ low (distance between animals greater than 2 meters, for individual calves and with a space greater than $8.5 \mathrm{~m} 2 /$ animal, for collective calves); Md = medium (distance less than 2 meters, but without contact between animals, in individual calve housing and with space between 5 and $8.5 \mathrm{~m} 2 /$ animal in collective calve housing); $\mathrm{H}=$ high (distance that allowed contact between calves, in the case of individual calve housing, and with space less than 5 $\mathrm{m}$ 2/animal, in the case of collective calve housing $)$; Type $(\mathrm{CS}=$ collective stall; $\mathrm{CP}=$ collective picket; $\mathrm{TH}=$ tropical house; $\mathrm{SC}=$ suspended cage; $\mathrm{SS}=$ single-story cage; $\mathrm{A}=$ Argentinean type; $\mathrm{GC}=$ cage; $(\mathrm{I})=$ individual; $(\mathrm{C})=$ collective; $(\mathrm{Mi})=$ mixed $) ; \mathrm{Floor}(\mathrm{C}$ = concrete; $\mathrm{E}=$ earth; $\mathrm{S}=$ sand; $\mathrm{W}=$ wood; $\mathrm{R}=$ rubber $)$; Location $(\mathrm{S}=$ Shed; $\mathrm{P}=$ picket $)$; Bed $(\mathrm{Y}=$ yes; $\mathrm{N}=$ no); Humidity $(\mathrm{A}=$ adequate; $\mathrm{H}=$ high); Sunlight $(\mathrm{A}=$ adequate; $\mathrm{AB}=$ shaded; $\mathrm{P}=$ permanent $)$; Cleaning $(\mathrm{P}=$ performed; $\mathrm{I}=$ infrequent; $\mathrm{N}=$ not performed); Ventilation $(\mathrm{P}=$ present; $\mathrm{AB}=$ absent $)$; Maintenance $(\mathrm{Y}=$ yes; $\mathrm{N}=\mathrm{no}) ; \mathrm{I} \%$ - 5\% iodine tincture; I10\% - 10\% iodine tincture; NR - not performed; SID - 1 time/day; TID - three times/day. 1D - 1 day, 3D - 3 days, 4D - 4 days; 2L - 2 liters, 4L - 4 liters. $6 \mathrm{~L}-6$ liters; $\mathrm{Ba}$ - baby bottle, $\mathrm{T}$ - trough, $\mathrm{B}$ - bucket. Data that has not been entered is represented by $*$ symbol.

Regarding the care of the umbilicus, information was obtained regarding antisepsis, whether it was performed $(15 / 16 ; 93.57 \%)$; the use of established antiseptic, iodine tincture $(15 / 16 ; 93.57 \%)$, in concentrations of $5 \%(1 / 16 ; 6.2 \%)$ or $10 \%(10 / 16$; $62.5 \%)$. Information was also obtained regarding if antisepsis was performed once $(8 / 16 ; 50 \%)$ or three $(1 / 16 ; 6.2 \%)$ times a day, being performed only on the first post-birth day $(3 / 16 ; 18.75 \%)$, second $(1 / 16 ; 6.2 \%)$, third $(3 / 16 ; 18.75 \%)$, or fifth $(4 / 16 ; 25 \%)$ day, and if the umbilical stump was cut immediately after birth $(6 / 16 ; 37.5 \%)$.

Regarding food, information was obtained regarding the colostrum supply on the first $(1 / 16$; $6.2 \%)$, third $(7 / 16 ; 43.75 \%)$, or fourth $(2 / 16$;
$12.5 \%)$ day, in the amount of $2(1 / 16 ; 6.2 \%), 4$ $(5 / 16 ; 31.25 \%)$, or $6(4 / 16 ; 25 \%)$ liters per baby bottle $(9 / 16 ; 56.25 \%)$, in the trough $(1 / 16 ; 6.2 \%)$ or bucket $(1 / 16 ; 6.2 \%)$. The data obtained in relation to umbilical care and colostrum according to each property are shown in Table 2.

After physical and ultrasound examination of the umbilical region, it was found that, of the 806 animals, 52 calves had alterations compatible with omphalopathies $(6.45 \%)$. The prevalence of fibrosis or inflammatory changes in each property is shown in Figure 1.

Of the 52 animals analyzed, $13(25 \%)$ showed fibrosis changes and $39(75 \%)$ showed changes 
compatible with inflammation of one or more umbilical components. There was a difference $(\mathrm{P}$ $=0.0034)$ in the correlation between properties and umbilical inflammation, with the highest prevalence of inflammatory changes observed in properties 2 (tropical house $(4 / 33 ; 12.12 \%)), 3$ (collective stall $(6 / 42 ; 14.29 \%)$ ), 6 (tropical house
$(5 / 23 ; 21.74 \%)), 7$ (collective picket (2/17; $11.76 \%)$ ), and 16 (collective picket with chain $(4 / 18 ; 22.22 \%))$. Of the 16 properties studied, only two did not identify umbilical changes, and in nine of them $(56.25 \%)$, there was a predominance of inflammatory umbilical changes.
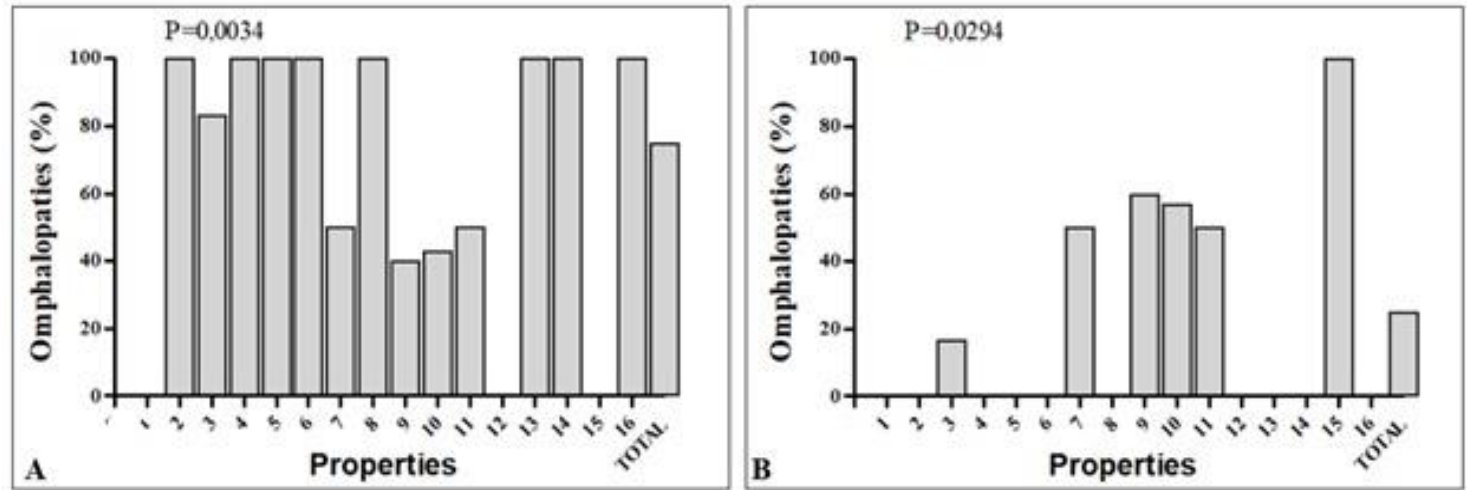

In properties 1 and 12, no animals with umbilical disorders were found.

Figure 1. Prevalence of inflammatory (A) and fibrosis (B) omphalopathies according to each property, confirmed by ultrasound examination.

Serum from the 39 animals diagnosed with inflammatory omphalopathies was analyzed, and the mean values and standard deviations of TP $(5.2 \pm 0.29 \mathrm{~g} / \mathrm{dL})$, GLOB $(2.62 \pm 0.33 \mathrm{~g} / \mathrm{dL})$, and GGT (135.91 \pm 427.17 IU/L) were obtained. Of the total number of animals evaluated, 14 (35.89\%) were diagnosed with FPIT, as they presented values below the established cutoff point (properties 2, 3, and 11). Properties 2 and 3 contained more than $50 \%$ of the animals with FPIT.

Risk factors related to the onset of inflammatory omphalopathies were established (Tab.3). Logistic regression analysis identified an association between inflammatory omphalopathies and the following risk factors: herd size (small or medium); types of calve housing (individual or collective; ground, suspended calve housing, with or without side protection); types of flooring in calve housing (earth, sand); shed or picket and sunlight exposure. The risk of omphalopathies decrease in properties that have used rubber floor.

\section{DISCUSSION}

In this study, it was possible to determine the types of facilities in 16 dairy farms, the prevalence of omphalopathies in each of them, the associations between the types of calve housing with the development of these diseases, and the risk factors related to the appearance of umbilical changes with inflammatory characteristics.

Eight different types of calve housing found in our study reinforce the fact that still no consensus has been reached on which would be the best type to be implemented on dairy farms. There are many factors that must be considered when choosing the type of calve housing to be installed on a property, such as geographic location, air temperature and humidity, rainfall, population density, and availability of manpower. However, it is considered an efficient installation when there is environmental quality and comfort for the animals, in addition to being practical and low cost (Campos et al., 2005). The literature recommends individual calve housing (houses or cages), since they allow the reduction of the horizontal transmission of pathogens (Santos et al., 2001; Bittar and Slazon, 2018). The tropical house was the most prevalent installation found in the evaluated properties. 
Risk factors...

Table 3. Logistic regression analysis determining risk factors for the onset of inflammatory omphalopathies in calves

\begin{tabular}{|c|c|c|c|c|c|c|c|}
\hline Characteristics & Categories & Risk factors & $\begin{array}{l}\text { Regression } \\
\text { coefficient }\end{array}$ & SEM & $\begin{array}{l}\text { Odds } \\
\text { ratio }\end{array}$ & $95 \% \mathrm{CL}$ & $\mathrm{p}$ value \\
\hline Farms conditions & Herd size & $\begin{array}{c}\text { Small } \\
\text { Medium }\end{array}$ & $\begin{array}{c}\text { reference } \\
-0.341\end{array}$ & 0.1401 & 0.5 & $0.29-0.87$ & 0.0149 \\
\hline \multirow{4}{*}{$\begin{array}{l}\text { Calve housing } \\
\text { conditions }\end{array}$} & $\begin{array}{l}\text { Individual or } \\
\text { collective }\end{array}$ & $\begin{array}{l}\text { Individual } \\
\text { Collective }\end{array}$ & $\begin{array}{c}\text { reference } \\
0.3189\end{array}$ & 0.1647 & 1.89 & $0.99-3.61$ & 0.0529 \\
\hline & \multirow[t]{2}{*}{ Density } & $\begin{array}{l}\text { Low } \\
\text { Medium }\end{array}$ & $\begin{array}{l}-0.0784 \\
\text { reference }\end{array}$ & 0.2188 & 0.87 & $0.38-1.99$ & 0.72 \\
\hline & & High & -0.2954 & 0.1881 & 0.6 & $0.29-1.25$ & 0.1163 \\
\hline & Type & $\begin{array}{c}\text { Suspended } \\
\text { Not suspended } \\
\text { Side protection (yes) } \\
\text { Side protection (no) }\end{array}$ & $\begin{array}{l}\text { reference } \\
1.0119 \\
\text { reference } \\
0.5364\end{array}$ & $\begin{array}{l}0.3393 \\
0.2258\end{array}$ & $\begin{array}{l}7.56 \\
2.92\end{array}$ & $\begin{array}{l}2-28.61 \\
1.2-7.08\end{array}$ & $\begin{array}{l}0.0029 \\
0.0175\end{array}$ \\
\hline \multirow{4}{*}{$\begin{array}{l}\text { Accommodation } \\
\text { features }\end{array}$} & \multirow[t]{2}{*}{ Floor } & $\begin{array}{l}\text { Earth } \\
\text { Sand } \\
\text { Rubber } \\
\text { Concrete }\end{array}$ & $\begin{array}{c}\text { reference } \\
1.8238 \\
-1.4526 \\
-0.5363\end{array}$ & $\begin{array}{c}0.4612 \\
0.604 \\
0.4299\end{array}$ & $\begin{array}{l}2.99 \\
0.11 \\
0.28\end{array}$ & $\begin{array}{l}1.18-7.56 \\
0.02-0.52 \\
0.09-0.84\end{array}$ & $\begin{array}{l}<.0001 \\
0.0162 \\
0.2122\end{array}$ \\
\hline & & Wood & -0.5635 & 0.3585 & 0.27 & $0.11-0.68$ & 0.116 \\
\hline & Location & $\begin{array}{l}\text { Picket } \\
\text { Shed }\end{array}$ & $\begin{array}{c}\text { reference } \\
0.4938\end{array}$ & 0.1938 & 2.68 & $1.25-5.73$ & 0.0108 \\
\hline & Sunshine & $\begin{array}{l}\text { Present } \\
\text { Absent }\end{array}$ & $\begin{array}{c}\text { reference } \\
0.4871\end{array}$ & 0.2501 & 2.64 & $0.99-7.05$ & 0.0514 \\
\hline $\begin{array}{l}\text { Umbilical } \\
\text { management }\end{array}$ & $\begin{array}{l}\text { Antisepsis } \\
\text { period }\end{array}$ & $\begin{array}{l}1 \text { day } \\
3 \text { days } \\
4 \text { days }\end{array}$ & $\begin{array}{c}- \\
0.0735 \\
-0.4148 \\
\text { reference }\end{array}$ & $\begin{array}{l}0.3075 \\
0.2419\end{array}$ & $\begin{array}{c}0.57 \\
0.4\end{array}$ & $\begin{array}{l}0.18-1.79 \\
0.15-1.04\end{array}$ & $\begin{array}{l}0.8111 \\
0.0865\end{array}$ \\
\hline Colostrum & $\begin{array}{c}\text { FPIT } \\
\text { (percentage) }\end{array}$ & $\begin{array}{c}\text { Mean (until 50\%) } \\
\text { High }(>50 \%)\end{array}$ & $\begin{array}{c}\text { reference } \\
1.1386\end{array}$ & 0.6065 & 6.41 & $\begin{array}{l}1.11- \\
36.82\end{array}$ & 0.0605 \\
\hline
\end{tabular}

The prevalence of omphalopathies was $6.45 \%$, which was lower than the $42.22 \%$ and $50 \%$ rates obtained by Reis et al. (2009) and Melo Neto et al. (2013), respectively. Both the studies highlighted that umbilical disorders could be related to hygiene problems and other care with the navel shortly after birth, since Melo Neto et al. (2013) found that $80 \%$ of the properties studied did not perform umbilical antisepsis, whereas in our study, only $6.2 \%$ did not adopt this practice. Although this rate is lower than that of other studies, it was found that even with antisepsis, it is not considered adequate in all seven properties that had the highest rates of inflammatory omphalopathies.
Ten percent iodine was the most used solution; however, the duration of antisepsis was either very high ( 3 to 5 days) or very low (1 day). In humans, $10 \%$ iodine causes iatrogenic omphalitis (Lavan et al., 1994); hence, it is recommended that this solution be used only on the first day of life, followed by the use of $5 \%$ or $2 \%$ iodine solutions or $0.5 \%$ chlorhexidine or $2 \%$ (Wieland et al., 2016) or 4\% (Fordyce et al., 2018), with no differences in efficacy between these antiseptics. The duration should include the complete dehiscence of the umbilical stump, which usually occurs within 10 days after birth (Souza Faria et $a l ., 2017)$, preventing the entry of pathogens.

Another important factor related to the development of omphalopathies is effective 
colostrum management and supply, which includes quality, quantity, and time of administration. The gold standard of colostrum quality is linked to immunoglobulin $\mathrm{G}$ levels, which must be $\geq 50 \mathrm{mg} / \mathrm{mL}$, as determined by a colostrometer, or $\geq 25 \%$, as determined by the Brix-type refractometer. The quantity and speed must necessarily follow $10 \%$ of the body weight at birth (BWB) of high-quality colostrum $(\geq 25 \%$ of Brix) in the first meal, by bottle or tube, until 2 hours of life. Further, an additional $5 \%$ of the BWB must be provided, in the second feeding, without forcing ingestion, in up to 8 hours of life (Godden et al., 2019; Azevedo et al., 2020). In the seven most prevalent properties for omphalopathies, it was found that in three of them, the amount of colostrum offered was below the recommended value, no data were obtained on the time of colostrum offering after calves were born, or whether the colostrum was fresh, from their own mothers, or frozen.

Calves are agammaglobulinemic at birth and need colostral protection for their survival; thus, an improper management of colostrum leads to failure in passive immunity transfer (FPIT), which combined with other relevant factors for the management of newborns, considerably increases the risk of death in these animals (Marchionatti et al., 2015; Barry et al., 2019). In our study, the duration os umbilical antisepsis is not associated with omphalopathies and not an association between FPIT and omphalopathies. However, it is know failure in the transfer of passive immunity negatively affects the health of the calves, increasing the risks of morbidity and mortality (Abuelo et al., 2019) up to 6 months of life (Zakian et al., 2018).

In a study by Novo et al. (2017), a prevalence rate of $30 \%$ of umbilical inflammation was found in calves that received frozen colostrum. Among the animals that received fresh colostrum, there were no diseases, highlighting the importance of the quality of colostrum for the prevention of these conditions.

To classify umbilical diseases as inflammatory and fibrosis, in addition to umbilical palpation, ultrasound examination was performed, making it possible to observe fluid in the affected region, thickening of vessel walls, or even abscesses, characterizing inflammatory changes. In the animals that presented fibrosis in the umbilicus, it was possible to visualize the presence of dense, hyperechoic tissue on examination, characterizing fibrosis of the region (Seino et al., 2016).

On analyzing the data obtained in the application of the questionnaires, it was noted that omphalopathies was more prevalent in collective facilities and with a high density of animals (pens and pickets), in which there was a greater contact between animals and ease of proliferation of agents causing umbilical diseases. Accidents may also occur because of the animal's sucking habits, causing injuries and an inflammatory process in the region (Vinholis et al., 2018 Rengifo et al., 2006). Such characteristics no indicate that the collective calve housing acted as risk factors for the emergence of omphalopathies, as verified by the association in the logistic regression test.

Although some authors recommend collective housing, as they allow the possibility of interaction between animals, reducing stress (Chua et al., 2002), care with this type of accommodation is important, as cleaning the environment is hampered by the greater number of animals and greater presence of dirt. This care must be even greater when there is a high density of animals, which in addition to causing competition for food, leads to greater transmission of diseases (Vinholis et al., 2018 Bittar and Slanzon, 2018). The high density of animals in the calve housing not was determined as a risk factor for the emergence of umbilical disorders, but collective calves were considered as a risk factor.

In Brazil, a large part of the allocation of calves is performed in individual tropical houses, whose management recommends avoiding the proliferation of diseases and breaking the pathogen life cycle, since it is a mobile calve housing (Oliveira et al., 2005). However, it was observed in this study that animals that are allocated to ground calve housing, as is the case with houses and ground cages, are more likely to have umbilical diseases, which can occur if the environment is not properly cleaned, since feces and urine are in contact with animals, causing an inappropriate environment (Oliveira et al., 2005). In this sense, the suspended cages facilitate cleaning, as the dirt usually drains to the bottom, allowing hygiene without the need to remove the animals; thus, facilitating handling and causing fewer diseases, as was the case with properties 4 
and 14, which exclusively used this type of accommodation.

Another important point that must be considered during the planning and construction of calve housing is the protection of the animals against the weather (Paranhos and Morales, 2011). Allocations must have sunshine, with the possibility of protection and natural ventilation, guaranteeing the renewal of air and elimination of gases generated by the accumulation of excreta, and they must offer protection against the wind (Oliveira et al., 2005). However, it does not occur in some types of calves, such as those of the Argentine type, from properties 8 and 10, and for animals that are kept in the picket. In property 16, where the animals were kept exclusively in pickets, many sick animals were found $(22.22 \%)$.

The absence of lateral protection was considered a risk factor related to the emergence of omphalopathies, and calve housing located in closed sheds, without adequate ventilation, as in property 3, in which animals were kept in collective stalls, without windows, sunlight, and adequate ventilation was also a risk factor. Housing that is free from sunlight is also a risk factor for omphalopathies, as these are environments with higher humidity, with an easy proliferation of pathogens and spread of diseases (Vinholis et al., 2018.

However, in relation to the housing, attention must be paid to the type of floor during its construction, as this was also decisive for the onset of the disease. The abrasiveness of sand cause injuries when the animal lies down or lifts, allowing pathogens to enter the umbilical region (Marchionatti et al., 2015. However, rubber floors reduces this risk, probably due to the lower surface abrasiveness and ease of washing (Oliveira et al., 2005).

Regarding the characteristics of the farms studied, another factor that had an impact on omphalopathies was the size of the herds, and in this study only those of small or medium size were evaluated, since there was no property with more than 500 animals in lactation. Those with medium size were more likely to have animals with umbilical diseases, when compared to small ones. This may be owning to the fact that smaller farms have fewer neonatal calves, making it easier for employees to pay more attention to neonatal care.
During the analysis of the properties and care given to calves, it was possible to notice that the presence of omphalopathies may be related to several factors related with some aspects related to the housing of the animals, which should be evaluated in properties with a large number of calves with umbilical diseases. The management of calves within a milk production system is extremely important, as the good performance of these animals will result in a satisfactory production, presenting great relevance; thus, preventing the diseases, such as omphalopathies, most observed during this critical period of the life of these animals.

\section{CONCLUSIONS}

Although there is no standardization in relation to the types of calve housing in the studied region, it was possible to verify in this study that the greater the number of animals in the herd; calves kept in sheds, in collective facilities; or in individual ground calve housing and without side protection; sand floor; and in places without incidence of sunlight, the calves were more prone to the development of inflammatory omphalopathies, since these are considered risk factors.

\section{REFERENCES}

ABUELO, A.; HAVRLANT, P.; WOOD, N.; HERNANDEZ-JOVER, M. An investigation of dairy calf management practices, colostrum quality, failure of transfer of passive immunity, and occurrence of enteropathogens among Australian dairy farms. J. Dairy Sci., v.102, p.8352-8366, 2019.

AZEVEDO, R.A.; FERNANDES, R.C.; PIRES JR, O.S.; DUARTE, E.R. Manejo e instalações para cria de bezerros leiteiros. Zootecnia Brasil O portal da Zootecnia, 2008. Available in: http://www.zootecniabrasil.com.br/sistema/modu les/smartsection/print.php?itemid=46. Accessed in: 1 May 2020.

AZEVEDO, R.A.; TEIXEIRA, A.M.; BITTAR, C.M. et al. Alta cria. Uberaba: Alta Genetics, 2020. Available in: https://www.researchgate.net/ publication/346420263_Alta_CRIA_2020.

Accessed in: 1 May 2020.

BAIRD, A.N. Umbilical surgery in calves. veterinary clinics: Food Anim. Pract., v.24, p.467-477, 2008. 
BARRY, J.; BOKKERS, E.A.M.; BERRY, D.P. et al. Associations between colostrum management, passive immunity, calf-related hygiene practices, and rates of mortality in preweaning dairy calves. J. Dairy Sci., v.102, p.10266-10276, 2019.

BITTAR, C.M.M.; FERREIRA, L.S. Bem estar de bezerros. Parte 1: Instalações, 2010. Available in: https://www.milkpoint.com.br/colunas/carlabittar/bemestar-de-bezerros-parte-1-instalacoes65591n.aspx. Accessed in: 21 May 2019.

BITTAR, C.M.M.; SLAZON, G.S. Bezerreiros coletivos: quando e por que utilizar?, 2018. Available in: https://www.milkpoint.com.br/ colunas/carla-bittar/bezerreiros-coletivos-

quando-e-por-que-utilizar-210214/. Accessed in: 21 Sep. 2020.

BOMBARDELLI, J.A.; SEINO, C.H.; REIS, G.A. et al. Aspectos ultrassonográficos dos componentes umbilicais de bezerros da raça Holandesa durante o processo de involução fisiológica. Arq. Bras. Med. Vet. Zootec., v.70, p.382-390, 2018.

CAMPOS, A.T.; KLOSOWSKI, E.S.; GASPARINO, E.; CAMPOS, A.T.; SANTOS, W.B.R. Análise térmica de abrigos individuais móveis e sombrite para bezerros. Acta Sci. Anim., v.27, p.153-161, 2005.

CHUA, B.; COENEN, E.; VAN DELEN, J.; WEARY, D. M. Effects of pair versus individual housing on the behavior and performance of dairy calves. J. Dairy Sci., v.10, p.360-364, 2002.

DESROCHERS, A.; FRANCOZ, D. Clinical management of septic arthritis in cattle. Vet. Clin. North Am. Food Anim. Pract., v.30, p.177-203, 2014.

FEITOSA, F.L.F.; CAMARGO, D.G.; YANAKA, R. et al. Índices de falha de transferência de imunidade passiva (FTIP) em bezerros holandeses e nelores, às 24 e 48 horas de vida: valores de proteína total, de gamaglobulina, de imunoglobulina $\mathrm{G}$ e da atividade sérica de gamaglutamiltransferase, para o diagnóstico de FTIP. Pesqui. Vet. Bras., v.30, p.696-704, 2010.

FORDYCE, A.L.; TIMMS, L.L.; STALDER, K.J.; TYLER, H.D. Short communication: The effect of novel antiseptic compounds on umbilical cord healing and incidence of infection in dairy calves. J. Dairy Sci., v.101, p.1-5, 2018.
GODDEN, S.M.; LOMBARD, J.E.; WOOLUMS, A.R. Colostrum management for dairy calves. Vet. Clin. North Am. Food Anim. Pract., v.35, p.535-556, 2019.

GUERRI, G.; VIGNOLI, M.; PALOMBI, C.; MONACI, M.; PETRIZZI, L. Ultrassonographic evaluation of umbilical structures in Holstein calves: A comparison between healthy calves and calves affected by umbilical disorders. J. Dairy Sci., v.103, p.2578-2590, 2019.

HILL, J.A.G. Transferência de imunidade passiva colostral em bezerras neonatas da Região Metropolitana de Curitiba, Palmeira e Carambeí, Estado do Paraná e suas interrelações. 2010. 149f. Tese (Doutorado em Medicina Veterinária) - Faculdade de Medicina Veterinária e Zootecnia, Universidade de São Paulo, São Paulo, SP.

HOPKER, A. Umbilical swellings in calves: a continuing challenge. Vet. Rec., v.174, p.219-220, 2014.

LAVAN, R.P.; MADIGAN, J.; WALKER, R.; MULLER, N. Effects of disinfectant treatments on the bacterial flora of the umbilicus of neonatal foals. ANNUAL CONVENTION OF THE AMERICAN ASSOCIATION OF EQUINE PRACTITIONERS, 40., 1994, Vancouver. Proceedings... Vancouver, Canada: American Association of Equine, 1994. p.37-38.

MARCHIONATTI, E.; NICHOLS, S.; BABKINE, M. et al. Surgical management of omphalophlebitis and long term outcome in calves: 39 cases (2008-2013). Vet. Surg., v.45, p.194-200, 2015.

MELO NETO, G.B.; CORREIA, D.A.B.; BAPTISTA FILHO, L.C.F.; YANAKA, R. Perfil clínico-epidemiológico de onfalopatias em bezerros de rebanhos leiteiros no município de Caetés-PE. In: JORNADA DE ENSINO, PESQUISA E EXTENSÃO, 13., 2013, Recife. Anais... Recife: JEPEX, 2013.

MULON, P.Y.; DESROCHERS, A. Surgical abdomen of the calf. Vet. Clin. North Am. Food Anim. Pract., v.21, p.101-132, 2005.

NOVO, S.M.F.; COSTA. J.F.R.; BACCILI, C.C. et al. Effect of maternal cells transferred with colostrum on the health of neonate calves. Res. Vet. Sci., v.112, p.97-104, 2017. 
OLIVEIRA, A.A.; AZEVEDO, H.C.; MELO, C.B. Criação de bezerras em sistemas de produção de leite, 2005. Available in: http://www.cpatc.embrapa.br/publicacoes_2005/ ct-38.pdf. Accessed in: 03 July 2019.

PARANHOS, M.J.R.; MORALES, A.M.T. Practical approach on how to improve the welfare in cattle. Rev. Colomb. Cienc. Pecu., v.24, p.347359, 2011.

REIS, A.S.B.; PINHEIRO, C.P.; LOPES, C.T.A. et al. Onfalopatias em bezerros de rebanhos leiteiros no nordeste do estado do Pará. In: CONGRESSO BRASILEIRO DE BUIATRIA, 8, 2009, Belo Horizonte, Anais... Belo Horizonte: Associação Brasileira de Buiatria, 2009.

RENGIFO, S.A.; SILVA, R.A.; PEREIRA, I.A. et al. Isolamento de agentes microbianos a partir de amostras de sangue e umbigo de bezerros mestiços neonatos. Braz. J. Vet. Res. Anim. Sci., v.43, p.442-447, 2006.

SANTOS, G.T.; CAVALIERI, F.L.; MASSUDA, E.M. Alguns aspectos econômicos e de manejo na criação de novilhas leiteiras. Revista Balde Branco, p.56-60, 2001.

SEINO, C.R.; BOMBARDELLI, J.A.; REIS, G.A. et al. Avaliação ultrassonográfica de componentes umbilicais inflamados em bezerros da raça Holandesa com até 30 dias de vida. Pesqui. Vet. Bras., v.36, p.492-502, 2016.

SOUZA FARIA, A.L.B.; CONRADO, L.A.L.; VANZELA, L.S.; VILLAVERDE, A.B.; MUNIN, E. Application of phototherapy for the healing of the navels of neonatal dairy calves. Lasers Med. Sci., v.32, p.1579-1586, 2017.

SPURWAY, J.; LOGAN, P.; PAK, S. The development, structure and blood flow within the umbilical cord with particular reference to the venous system. Aust. J. Ultrasond Med., v.3, p.97$102,2012$.

STUDDS, M.J.; DEIKUN, L.L.; SORTES, D.E.; PEMPEK, J.A; PROUDFOOT, K.L. Short communication: the effect of diarrhea and navel inflammation on the lying behavior of veal calves. J. Dairy Sci., v.101, p.11251-11255, 2018.
SZASZ, G. g-glutamyltranspeptidase. In: BERGMEYER, H.U. Methods of enzymatic analysis. 2.ed. New York: Academic Press, 1974. v.2, p.715-719.

USDA-NAHMS Dairy. Part 3: Health and management practices on U.S. dairy operations, 2014. Available in: https://www.aphis.usda.gov/ animal_health/nahms/dairy/downloads/dairy14/D airy14_dr_PartIII.pdf. Accessed in: 2 Oct. 2020

VINHOLIS, M.M.B.; TUPY, O.; PEDROSO, A.F.; PRIMAVESI, O.; BERNARDI, A.C.C. Avaliação dos impactos econômicos sociais e ambientais de tecnologias da Embrapa Pecuária Sudeste: Casinha tropical: abrigo móvel individual para bezerras, 2018. Available in: https://www.infoteca.cnptia.embrapa.br/bitstrea $\mathrm{m} / \mathrm{doc} / 47875 / 1 /$ documentos58.pdf. Accessed in: 21 Sep. 2020.

VIRTALA, A.M.; MECHOR, G.D.; GROHN, Y.T.; ERB. H.N. The effect of calfhood diseases on growth of female dairy calves during the first three months of life in New York State. J. Dairy Sci., v.79, p.1040-1049, 1996.

WATSON, E.; MAHAFFEY, M.B.; CROWELL, $\mathrm{W}$. et al. Ultrasonography of the umbilical structures in clinically normal calves. Am. J. Vet. Res., v.55, p.773-780, 1994.

WIELAND, M.; MANN, S.; GUARD, C.L.; NYDAM, D.V. The influence of 3 different navel dips on calf health, growth performance, and umbilical infection assessed by clinical and ultrasonographic examination. J. Dairy Sci., v.100, p.1-12, 2016.

WINDEYER, M.C.; LESLIE, K.E.; GODDEN, S.M. et al. Factors associated with morbidity, mortality, and growth of dairy heifer calves up to 3 months of age. Prev. Vet. Med., v.113, p.231$240,2013$.

ZAKIAN, A.; NOURI, M.; RASOOLI, A. et al. Evaluation of 5 methods for diagnosing failure of passive transfer in 160 Holstein calves. Vet. Clin. Pathol., v.47, p.275-283, 2018. 